\title{
Rancang Bangun Aplikasi Pengelolahan Data Penempatan TKI Asal Timor Ke Luar Negeri Berbasis Web Studi Kasus (BP3TKI) Kupang
}

\author{
Yabes Vridman Aril Wabang ${ }^{1}$, Paskalis A. Nani ${ }^{2}$, Ign. Pricher A.N. Samane ${ }^{3}$ \\ ${ }^{123}$ Program Studi Ilmu Komputer, Universitas Katolik Widya Mandira Kupang, \\ Jl. Jendral A. Yani No. 50-52, Kupang, Nusa Tenggara Timur, Indonesia \\ Email: yabesvridman@gmail.com ${ }^{* 1}$, paskalisnani@gmail.com², niragung@gmail.com³
}

\begin{abstract}
Abstrak
Badan Pelayanan Penempatan dan Perlindungan Tenaga Kerja Indonesia (BP3TKI) berwenang memberikan pelayanan bagi masyarakat yang ingin mencalonkan diri sebagai Tenaga Kerja Indonesia ( TKI). Dalam hal ini, tentunya Kantor BP3TKI mempunyai banyak data penting yang akan dikelolah dengan baik agar terjaga integritasnya. Semua data penting tersebut akan dikelolah pada bagian Penempatan Kantor BP3TKI. Dalam mengelolah data TKI, bagian penempatan menggunakan Microsoft Excel yang dikelolah oleh satu orang dan hanya menggunakan satu unit Personal Computer (PC) yang ada pada bagian penempatan. Dikarenakan data dikelolah oleh satu orang dengan satu PC dan tidak tersimpan dalam database, maka sangatlah mungkin akan terjadi kehilangan data yang selama ini sudah dikelolah jika suatu saat PC yang terdapat di bagian penempatan mengalami kerusakan, hal ini akan menyulitkan pegawai bagian penempatan dalam mencari data ketika diperlukan kembali. Untuk itu, maka dibuatlah "Rancang Bangun Aplikasi Pengelolahan Data Penempatan Tki Asal Timor Ke Luar Negeri Berbasis Web". Metode yang digunakan dalam sistem ini adalah Waterfall Model. Sistem ini dirancang berbasis web, menggunakan bahasa pemrograman PHP dan media penyimpanan database menggunakan MySql. Diharapkan sistem ini dapat mengelolah dan menyimpan data TKI dengan baik dan aman dan memudahkan proses pencarian data.
\end{abstract}

Kata kunci : BP3TKI, TKI, PHP, MySql, Waterfall

\begin{abstract}
The Indonesian Worker Placement and Protection Service Agency (BP3TKI) has the authority to provide services for people who wish to run for Indonesian Workers (TKI). In this case, of course the BP3TKI Office has a lot of important data that will be well managed so that its integrity is maintained. All important data will be processed in the Placement section of the BP3TKI Office. In managing TKI data, the placement section uses Microsoft Excel which is managed by one person and only uses one Personal Computer (PC) unit in the placement section. Because the data is managed by one person with one PC and is not stored in the database, it is very possible that the data that has been managed will be lost if one day the PC in the placement section is damaged, this will make it difficult for the placement employee to find data when required return. For this reason, a "Web-Based Design Of Data Processing Application For Placement Of Tki Order Of Timor Abroad Based On Web-Based" was made. The method used in this system is the Waterfall Model. This system is designed based on Web, using PHP programming language and database storage media using MySql. It is hoped that this system can manage and store TKI data properly and safely and facilitate the data search process.
\end{abstract}

Keywords : BP3TKI, TKI, Waterfall, PHP, Mysql, Waterfall 


\section{PENDAHULUAN}

Perkembangan pesat di bidang Teknologi Informasi sangat mempermudah dalam proses penyelesaian masalah-masalah yang rumit dalam waktu yang efisien. Saat ini perkantoran ataupun instansi-instansi banyak membutuhkan informasi yang cepat, tepat, dan akurat, sehingga pemanfaatan komputer secara optimal adalah salah satu cara untuk memenuhi kebutuhan tersebut.

Kantor Badan Pelayanan Penempatan dan Perlindungan Tenaga Kerja Indonesia (BP3TKI) merupakan kantor pelayanan bagi masyarakat yang ingin mencalonkan diri sebagai Tenaga Kerja Indonesia (TKI) yang akan bekerja di luar negeri. Menurut update data pada 29 Agustus 2018, banyaknya TKI ke luar negeri menurut negara tujuan, sektor, dan jenis kelamin di Provinsi Nusa Tenggara Timur yang dikelolah BP3TKI sejumlah 1739 dan data tersebut akan terus bertambah setiap bulannya.

Pengelolahan data TKI pada bagian Penetapan Kantor BP3TKI saat ini masih dilakukan secara manual, yaitu data-data calon TKI masih di-input dengan menggunakan microsoft office excel. Dilihat dari jumlah banyaknya data TKI yang harus di-input maka sangat mungkin akan terjadi kesalahan penginput-an data TKI, pencarian data TKI juga dilakukan dengan cara membuka kembali data-data TKI yang telah di-input pada microsoft office excel dan dicari satu per satu sesuai dengan data yang diinginkan, tentunya ini akan membutuhkan waktu yang lama, dikarenakan data TKI terus bertambah setiap bulannya, hal ini juga akan berakibat pada kesulitan pembuatan laporan bulanan, dikarenakan proses pencarian data yang memakan waktu. Proses pengolahan data saat ini dirasakan kurang maksimal, kurang efisien dan efektif.

Untuk mengatasi permasalahan yang ada, maka dikembangkan Sebuah "Rancang Bangun Aplikasi Pengelolahan Data Penempatan Tki Asal Timor Ke Luar Negeri Berbasis Web" untuk memudahkan pegawai dalam melakukan pengelolahan data TKI, pencarian data TKI dan pembuatan laporan bulanan. Aplikasi ini terkoneksi dengan $M y S q l$ sebagai media penyimpanan data TKI. Diharapkan aplikasi ini dapat membantu bagian seksi penetapan dalam hal pengelolahan dan pencarian data TKI dan pembuatan laporan bulanan yang lebih efektif dan efisien.

\section{METODE PENELITIAN}

Dalam perancangan pembuatan sistem menggunakan Waterfall Model dengan beberapa tahap metodologi penelitian. Tahap-tahapan tersebut sebagai berikut :

\subsection{Analisis}

Tahap ini merupakan tahap inisialisasi pendefinisian masalah untuk menyelesaikan permasalahan melalui pengumpulan data-data pada Kantor BP3TKI Kupang. Adapun metode yang digunakan dalam pengumpulan data adalah sebagai berikut:

\section{a. Observasi}

Pada tahap observasi dilakukan pengamatan terhadap sistem yang sedang berjalan pada Kantor BP3TKI Kupang tentang proses Penempatan TKI asal Timor ke luar negeri.

b. Wawancara

Pada tahap wawancara dilakukan tanya jawab secara langsung kepada pegawai Kantor BP3TKI Kupang Bagian Seksi Penempatan TKI terkait dengan masalah yang menjadi fokus penelitian.

c. Studi Pustaka

Pada tahap ini dikumpulkan beberapa literatur yang terkait tentang masalah yang menjadi fokus penelitian, termasuk didalamnya literatur mengenai hal-hal yang mendukung pembuatan sistem.

\subsection{Desain Sistem}

Pada proses desain sistem ini akan menerjemahkan syarat kebutuhan ke sebuah perancangan perangkat lunak yang dapat diperkirakan sebelum dibuat coding. Proses ini berfokus kepada struktur data, arsitektur perangkat lunak, representasi interface, dan detail (algoritma) prosedural. Pada tahap perancangan desain sistem mencakup beberapa aspek, yaitu:

a. Pembuatan pemodelan sistem dengan menggunakan: Flowchart, pembuatan bagan alir data (data flow diagram), ERD, perancangan input sistem, perancangan output sistem dan perancangan tampilan antar muka sistem. 


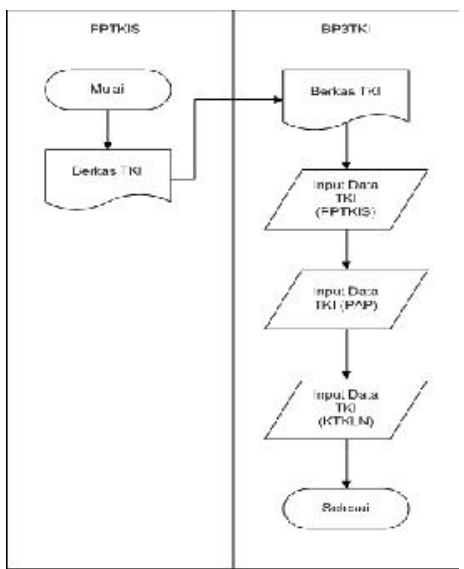

Gambar 1 Flowchart alur proses pendataan TKI yang sedang berjalan pada Kantor BP3TKI

b. Perancangan basis data sistem: mencakup penentuan kebutuhan file database dan parameter berupa tipe, media, organisasi, dan field kunci dari file yang digambarkan dalam bentuk kamus data dan diagram hubungan entitas.

c. Perancangan teknologi sistem: mencakup penentuan jenis teknologi hardware dan software, komunikasi data dan jumlah yang dibutuhkan.

d. Perancangan pengendalian sistem : mencakup pengendalian organisasi, dokumentasi, hardware, keamanan fisik, keamanan data dan komunikasi.

\subsection{Implementasi}

Pada tahap ini merupakan implementasi dari tahap desain perangkat lunak menjadi sistem secara utuh. Proses desain harus diterjemahkan dalam bentuk mesin yang bisa dibaca yaitu ke dalam bahasa pemrograman melalui proses coding. Dalam proses coding bahasa pemrograman yang digunakan adalah PHP dan MySql.

\subsection{Pengujian Sistem}

Pada tahap fase pengujian terkait dengan sistem yang dibuat. Hasil perancangan sistem yang dibuat untuk petugas di Kantor BP3TKI yang membutuhkan sistem untuk membantu menyelesaikan pekerjaan. Setelah sistem diuji tahap selanjutnya dilakukan kegiatan-kegiatan berkaitan dengan aspek pengembangan.

Pada tahap pengujian sistem terhadap program menggunakan metode black box, pengujian ini bertujuan untuk mengetahui kesalahan pada saat proses coding dan memastikan bahwa input-annya sesuai dengan yang diharapkan.

\subsection{Pemeliharaan}

Pemeliharaan suatu sistem diperlukan ketika sistem yang telah dibuat mengalami perubahan. Perubahan tersebut bisa karena dibutuhkannya pengembangan fungsional atau penambahan fitur-fitur baru sehingga sistem tersebut harus diperbaharui.

\section{HASIL DAN PEMBAHASAN}

\section{Tampilan Login}

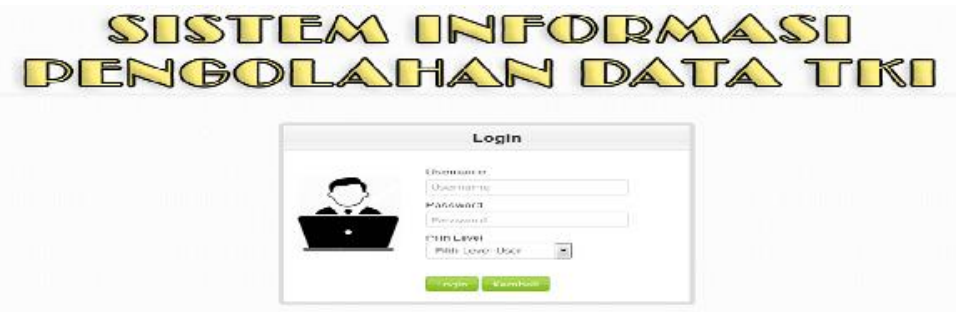

Gambar 1 Tampilan Login 
Tampilan ini muncul pertama kali ketika aplikasi dijalankan.

\section{Tampilan Home Penanggung Jawab}

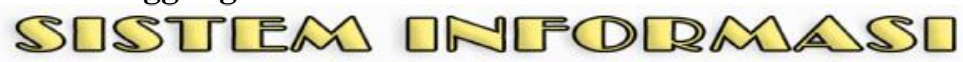

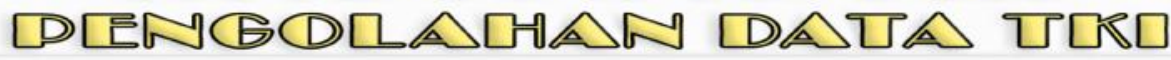

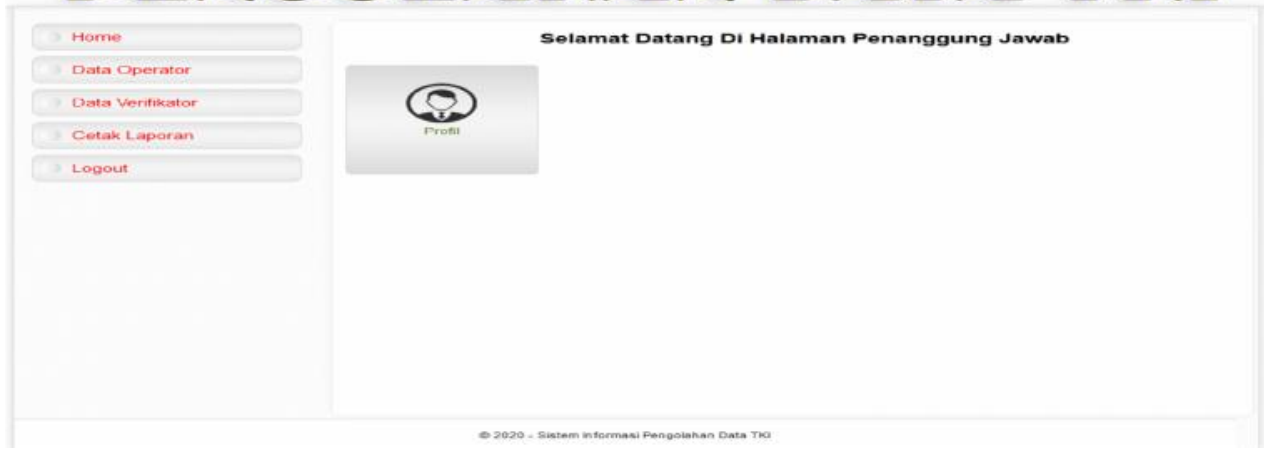

Gambar 1.2 Tampilan Home Penanggung Jawab

Tampilan Home Penanggung Jawab berisi menu profil penanggung jawab, menu tersebut untuk menampilkan data penanggung jawab.

\section{Tampilan Menu Data Operator}

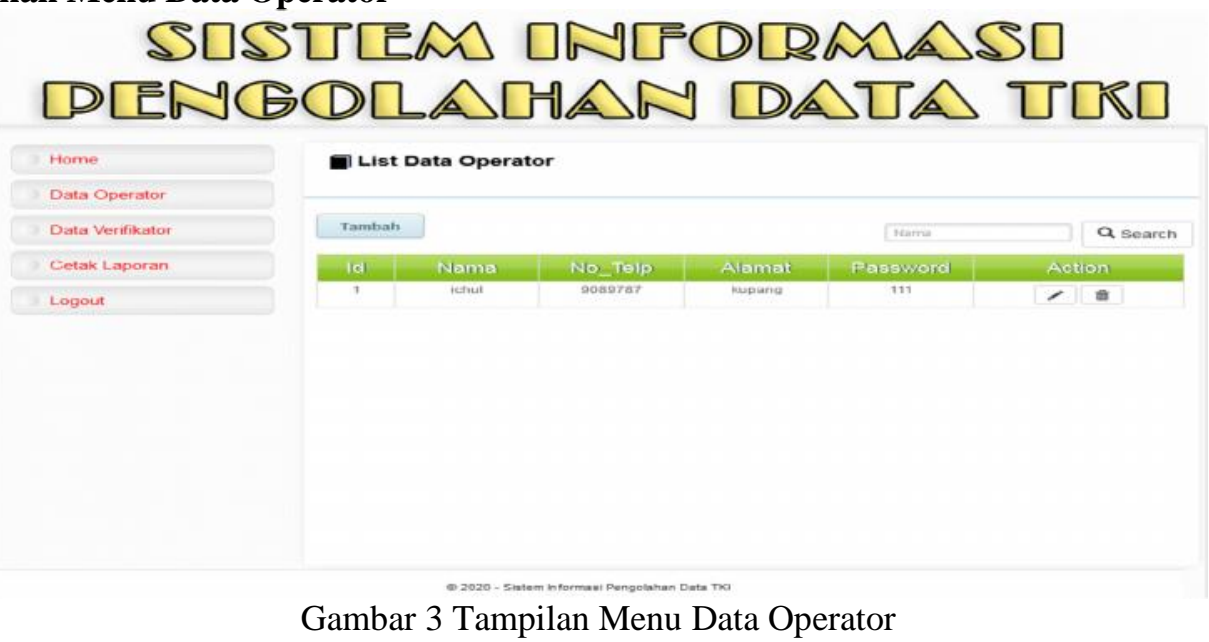

Tampilan menu data operator berfungsi untuk mengelolah data operator.

\section{Tampilan Menu Data Verifikator}

SDSULEM DNLFDLDMAST

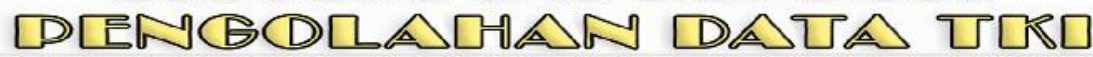

$$
\text { Home }
$$$$
\text { Dats operator }
$$$$
\text { Data vertikator }
$$$$
\text { Gelak Laporat }
$$$$
\text { Logout }
$$

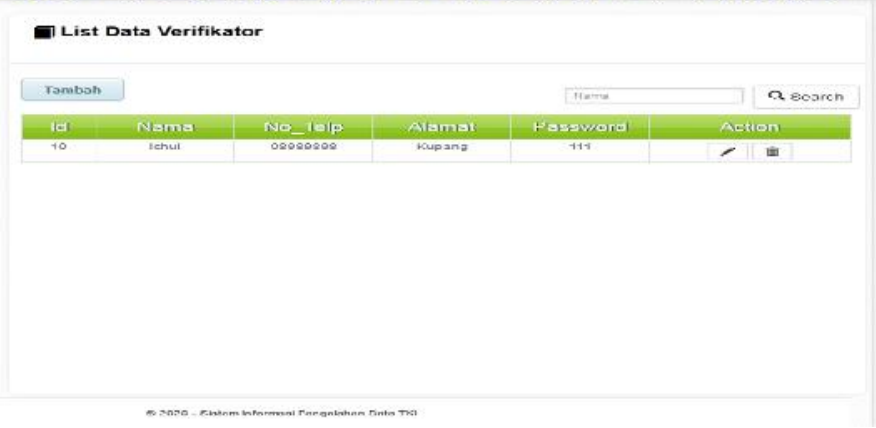

Gambar 4 Tampilan Menu Data Verifikator 
Tampilan menu data verifikator berfungsi untuk mengelolah data verifikator.

\section{Tampilan Menu Cetak Laporan}

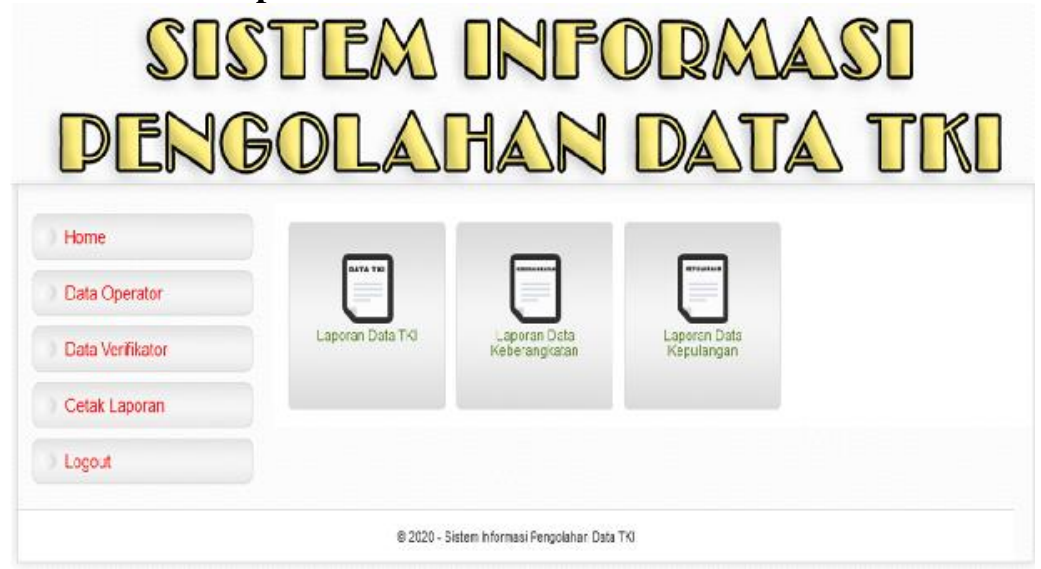

Gambar 5 Tampilan Menu Cetak Laporan

Pada tampilan ini terdapat tiga menu yaitu menu laporan TKI, menu laporan data keberangkatan, menu data laporan kepulangan

\section{Tampilan Menu Laporan Data TKI}

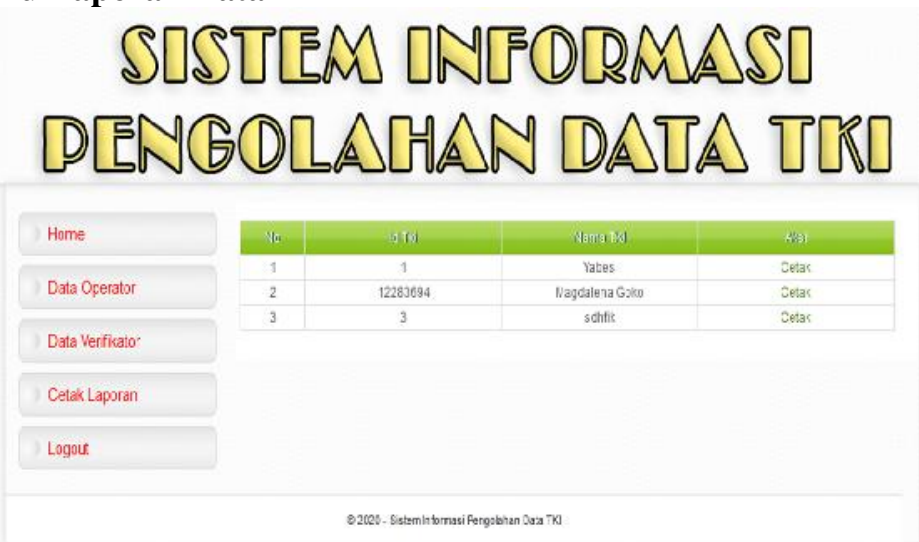

Gambar 6 Tampilan Menu Laporan Data TKI

Pada tampilan ini terdapat data-data TKI yang telah di-input kedalam sistem dan data tersebut bisa dicetak dengan menekan tombol cetak yang ada pada menu tersebut

\section{Tampilan Laporan Data TKI}

BALAI PELAYANAN PENEMPATAN DAN PERLINDUNGAN

TENAGA KERJA INDONESIA

KOTA KUPANG

PROVINSI NUSA TENGGARA TIMUR

\begin{tabular}{|c|c|c|c|c|c|c|c|c|}
\hline \multirow[b]{2}{*}{ 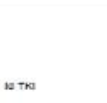 } & \multicolumn{7}{|c|}{ Data Tenaga Kerja Indonesia } & \multirow[b]{2}{*}{200020} \\
\hline & & : & Nams Lengerap & & rees & Nan & & \\
\hline tonts Keterats & : & 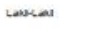 & Tenpes Tergye Lantr & & $1005-11 \cdot 21$ & suase & & Boun Kam \\
\hline venoniran & & sapens & agams & & knacak & name & & penna \\
\hline Norp & : & 0987:66r6 & Nama orang Tua & & sea tau & Name orang tua & & neer \\
\hline Nomp orang Tua & : & 896087527 & & & & & & \\
\hline Sextar Potergan & & intromai & Lens pexefan & & Tukang Kaoun & Negara Tuvan & & Maxpasa \\
\hline cas & : & 10000 & Nama Mapan & & Lesu Anmas & & & \\
\hline Desoer up & & 6645 & Tempen eneox up & & as unun & Hasa enosox up & & $\operatorname{sen} x$ \\
\hline Tempart Pelushen & : & anhos Ouats & Tampger Masux & & $2020-11-25$ & Tangosar atiessi & : & $2020-11-30$ \\
\hline No. Paspos & : & 9050 & Tampgsu teron & & $2020-10-20$ & Besonu tangess & & 2025-01-0 \\
\hline No. koen & & 909 & Loksu Tersh & & Kupano & талореа тегиt & & $2020-11-07$ \\
\hline Betaku thingsa & : & $2020 \cdot 11 \cdot 28$ & & & & & & \\
\hline
\end{tabular}

Gambar 7 Tampilan Laporan Data TKI 


\section{Tampilan Menu Laporan Data Keberangkatan}

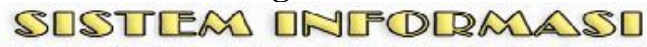

TDIENGCDR NTHAN TDETA TIRT

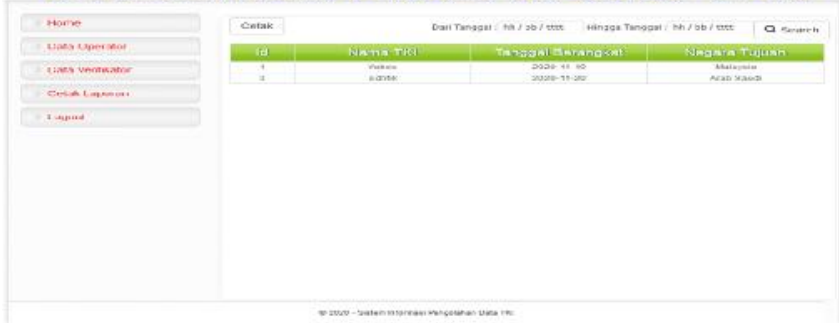

Gambar 8 Tampilan Menu Laporan Data Keberangkatan

Pada tampilan ini terdapat data-data keberangkatan tki yang telah di-input kedalam sistem dan data tersebut bisa dicetak dengan memilih tanggal, bulan dan tahun kemudian menekan tombol cetak yang ada pada menu tersebut.

\section{Tampilan Laporan Data Keberangkatan \\ BALAI PELAYANAN PENEMPATAN DAN PERLINDUNGAN \\ TENAGA KERJA INDONESIA KOTA KUPANG \\ PROUINSI NUSA TENGGARA TIMUR

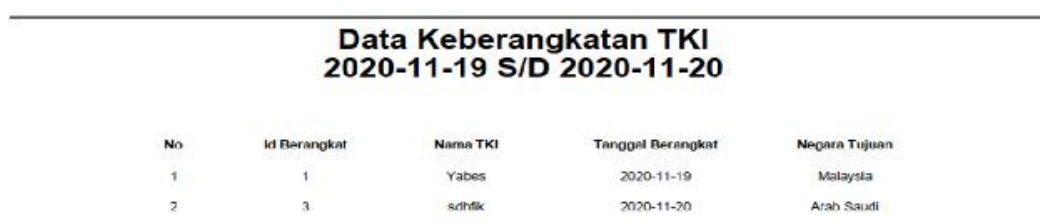

Gambar 9 Tampilan Laporan Data Keberangkatan

\section{Tampilan Menu Laporan Data Kepulangan}

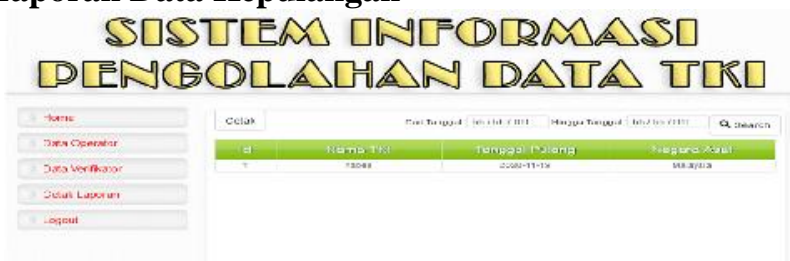

Gambar 10 Tampilan Menu Laporan Data kepulangan

Pada tampilan ini terdapat data-data kepulangan data tki yang telah di-input kedalam sistem dan data tersebut bisa dicetak dengan memilih tanggal, bulan dan tahun kemudian menekan tombol cetak yang ada pada menu tersebut.

\section{Tampilan Laporan Data Kepulangan}
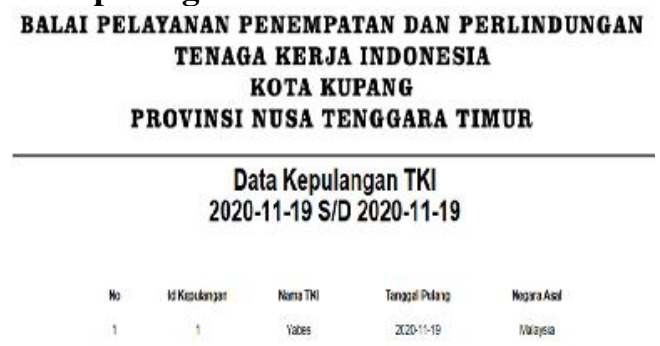

Gambar 11 Tampilan Laporan Data Kepulangan 


\title{
12. Tampilan Home Operator
}

\author{
SISTEEM ONTFCLRMAST
}

DPENGDLADAAN DATA URRD

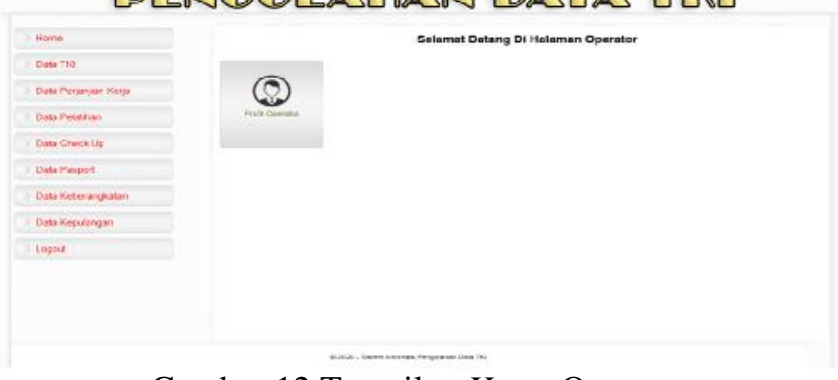

Gambar 12 Tampilan Home Operator

Tampilan Home operator berisi menu profil operator, menu tersebut untuk menampilkan data operator.

\section{Tampilan Menu Data TKI}

SISTEMM ONEPDRMASS

DPENGDLALANA DAUA URRD

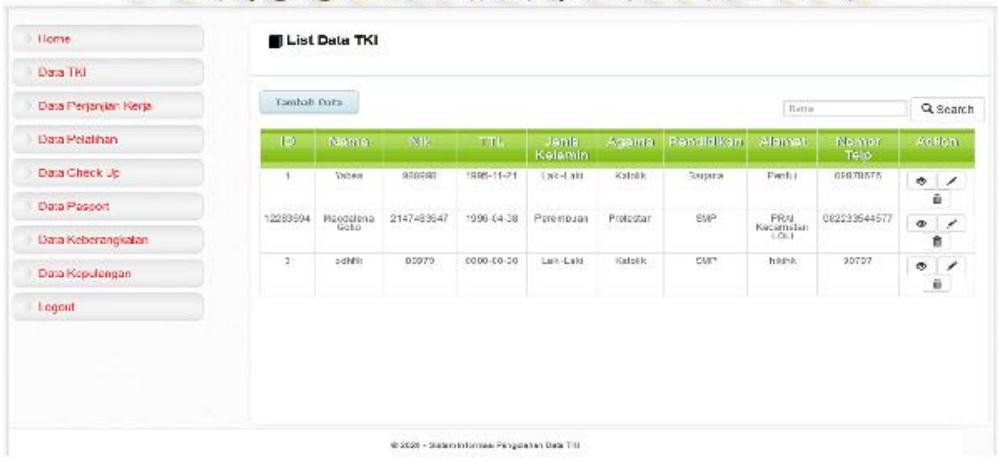

Gambar 13 Tampilan Menu Data TKI

Tampilan ini berfungsi bagi operator untuk melakukan pengolahan data TKI seperti tambah, edit, hapus dan melakukan pencarian data.

\section{Tampilan Menu Data Perjanjian Kerja}

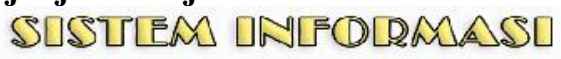

\section{DENGORAMAN DATA TRRT}

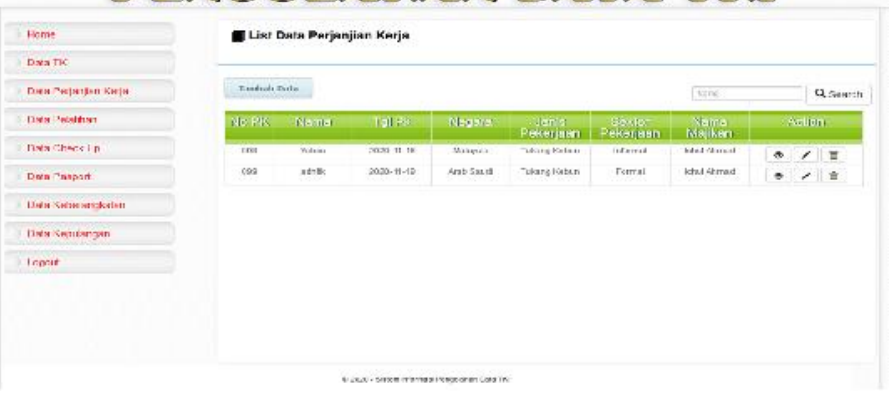

Gambar 14 Tampilan Menu Data Perjanjian Kerja

Tampilan ini berfungsi bagi operator untuk melakukan pengolahan data perjanjian kerja tki seperti tambah, edit, hapus dan melakukan pencarian data.

\section{Tampilan Menu Data Pelatihan}




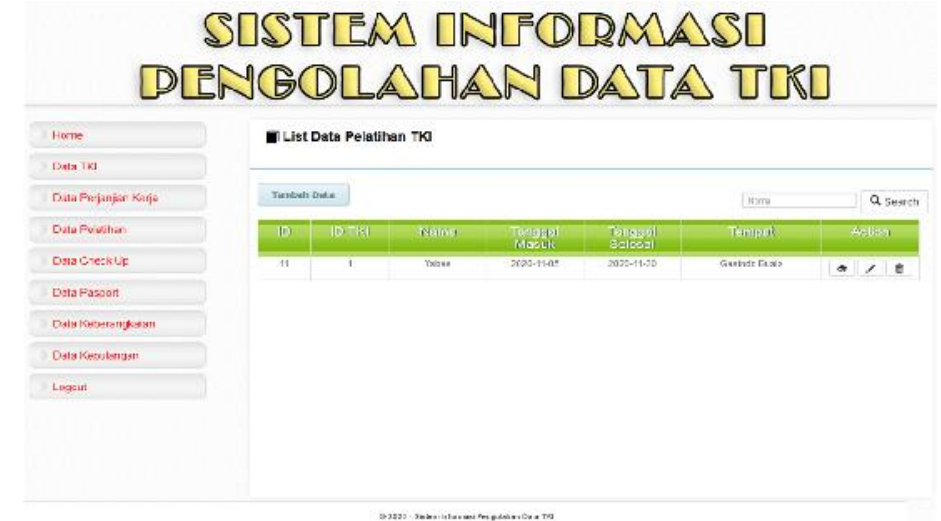

Gambar 15 Tampilan Menu Data Pelatihan

Tampilan ini berfungsi bagi operator untuk melakukan pengolahan data pelatihan TKI seperti tambah, edit, hapus dan melakukan pencarian data.

16. Tampilan Menu Data Check Up SUSTEEM OATEORMAOASO

DPENGTLADAN DAUA UTR

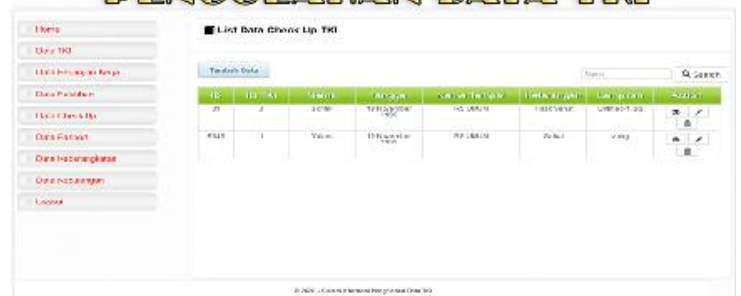

Gambar 16 Tampilan Menu Data Check Up

Tampilan ini berfungsi bagi operator untuk melakukan pengolahan data check up tki seperti tambah, edit, hapus dan melakukan pencarian data.

\section{Tampilan Menu Data Paspor}

SUSTLEM ONLFDLDADSSL

DENGOLATAAN DAUA URRT

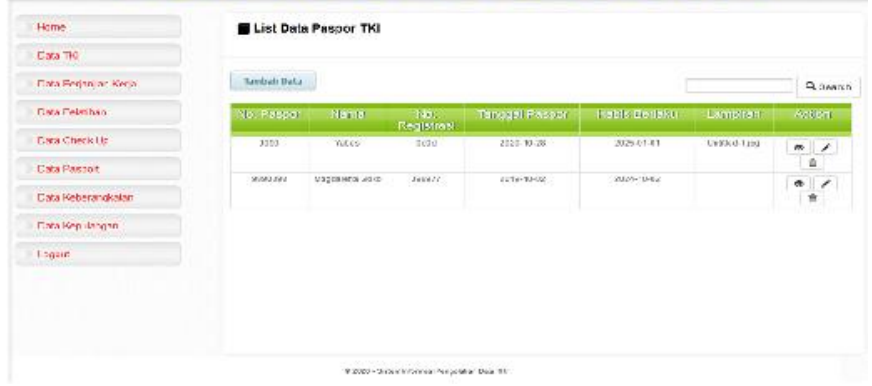

Gambar 17 Tampilan Menu Data Paspor

Tampilan ini berfungsi bagi operator untuk melakukan pengolahan data paspor TKI seperti tambah, edit, hapus dan melakukan pencarian data.

\section{Tampilan Menu Data Keberangkatan}




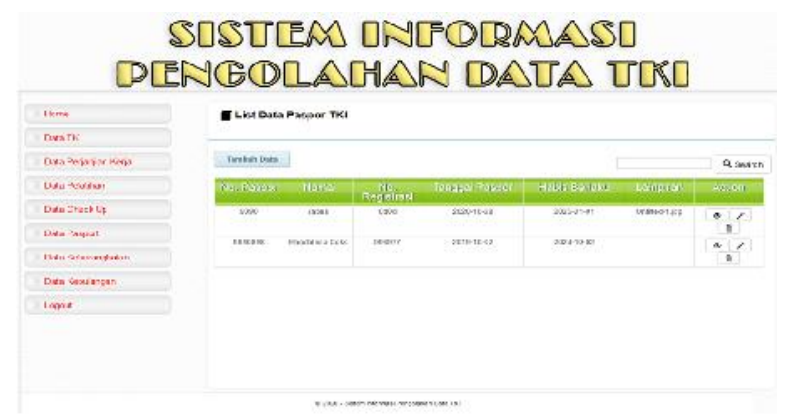

Gambar 18 Tampilan Menu Data Keberangkatan

Tampilan ini berfungsi bagi operator untuk melakukan pengolahan data keberangkatan TKI seperti tambah, edit, hapus dan melakukan pencarian data.

Tampilan ini berfungsi bagi verifikator untuk melakukan pengolahan data KTKLN TKI seperti tambah, edit, hapus dan melakukan cetak data KTKLN

\section{Tampilan Cetak Data KTKLN}

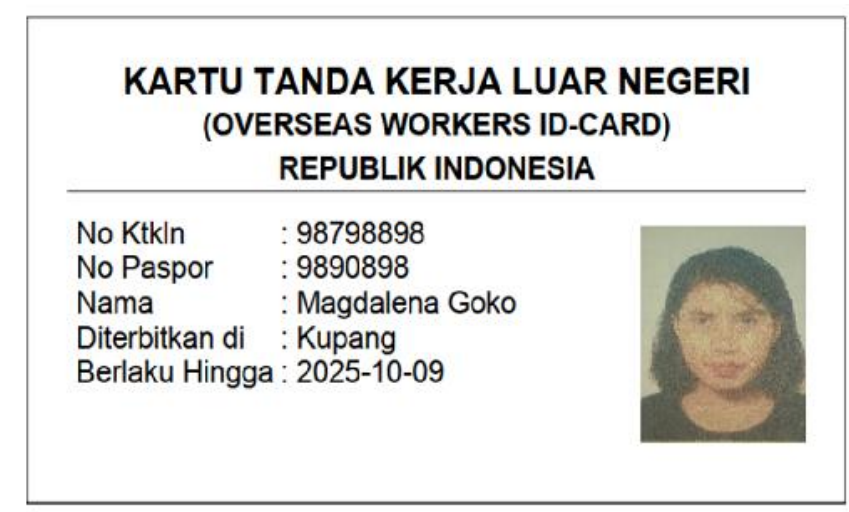

Gambar 19 Tampilan Cetak Data KTKLN

\section{KESIMPULAN}

Setelah melalui proses perancangan, proses implementasi, proses pengujian dan analisis hasil maka dapat ditarik kesimpulan secara umum bahwa sistem ini mampu mengatasi masalah yang terjadi pada Kantor BP3TKI Kupang berdasarkan identifikasi masalah yang tertuang dalam latar belakang masalah. Berikut adalah beberapa kesimpulannya :

1. Sistem ini mampu melakukan proses pengolahan data TKI, data pelatihan, data perjanjian kerja, data check up, data KTKLN, data keberangkatan dan data kepulangan.

2. Aplikasi ini mampu melakukan proses cetak data TKI, cetak data keberangkatan, cetak data kepulangan dan cetak data KTKLN.

\section{DAFTAR PUSTAKA}

1. Abdurahman, H., Riswaya, A. R. and Id, A. (2014) 'Aplikasi Pinjaman Pembayaran Secara Kredit Pada Bank Yudha BHakti', Aplikasi Pinjaman Pembayaran Secara Kredit Pada Bank Yudha BHakti, 8(2), pp. 61-69. Availableat:http://jurnal.stmik mi.ac.id/index.php/jcb/article/view/114/138.

2. Andi, J. (2015) 'Pembangunan Aplikasi Child Tracker Berbasis Assisted - Global Positioning System ( A-GPS ) Dengan Platform Android', Jurnal Ilmiah Komputer dan Informatika(KOMPUTA),1(1),pp.1-8.Availableat: elib.unikom.ac.id/download.php?id=300375. 
3. Andre (2017) Belajar HTML Dasar Part 1: Pengertian HTML, Duniailkom.Com.

4. Apriliyani, L. and Suryana, N. (2019) 'Analisis Dan Perancangan Aplikasi Pengelolaan Data Tenaga Kerja Asing ( Studi Kasus : Pt Cosmo Technology Cibadak )', pp. 9298.

5. Binarso, Y. A., Sarwoko, E. A. and Ba, N. bahtiar (2012) '434-853-1-Sm', Pembangunan Sistem Informasi Alumni Berbasis Web Pada Program Studi Teknik Informatika Universitas Diponegoro, 1(1), pp. 72-84.

6. Hartono, H. (2014) 'Pengertian Website Dan Fungsinya', Jurnal Ilmu Teknologi Informasi.

7. Indonesia, R. (2003) 'Undang-Undang Republik Indonesia No.13 Tahun 2003 tentang Ketenagakerjaan', Undang-undang No.13 Tahun 2003.

8. Iswandy, E., Komputer, D. S. T. M. I. and Padang, S. J. (2015) 'Sistem Penunjang Keputusan Untuk Menentukan Dan Santunan Sosial Anak Nagari Dan Penyaluran Bagi Mahasiswa Dan Pelajar Kurang Mampu', jurnal TEKNOIF, 3(2). doi: 2338-2724.

9. Norhan, L. and Kustandi, T. (2019) 'SISTEM INFORMASI PENDATAAN TENAGA KERJA INDONESIA BERBASIS WEB PADA PT . LAATANSA LINTAS INTERNASIONAL', 3(1), pp. 225-231.

10. Prasetyo, B., Pattiasina, T. J. and Soetarmono, A. N. (2015) 'Perancangan dan Pembuatan Sistem Informasi Gudang (Studi Kasus : PT. PLN (Persero) Area Surabaya Barat)', Teknika, 4(1), pp. 12-16. doi: 10.34148/teknika.v4i1.30.

11. Pressman (2010) 'Rekayasa Perangat Lunak. Pendekatan Praktisi', Yogyakarta:Andi Publisher.

12. Safwat S.R, Dewiyani Sunarto2, T. S. (2013) 'Rancang Bangun Sistem Informasi Umat Gereja Katolik Gembala Yang Baik Surabaya Berbasis Web', Jurnal Sistem Informasi, 2(2), pp. 1-8.

13. Susilo, G. (2014) “"TRANSFORMASI Jurnal Informasi \& Pengembangan Iptek”, 10(2), pp. 21-37.

14. Suteja, B. et al. (2015) 'Perancangan User Interface E-Learning Berbasis Web Perancangan User Interface E-Learning Berbasis Web', 2008(March), pp. 36-46

15. Widaningrum, I. D. A. (2012) 'RANCANGAN SISTEM INFORMASI DATA TENAGA KERJA INDONESIA DENGAN MENGGUNAKAN PHP DAN MYSQL', Multitek Indonesia, 6(2), pp. 141-150. 